\title{
The Escherichia coli 0157:H7 bovine rumen fluid proteome reflects adaptive bacterial responses
}

\author{
Indira T Kudva ${ }^{1 *}$, Thaddeus B Stanton ${ }^{1}$ and John D Lippolis²
}

\begin{abstract}
Background: To obtain insights into Escherichia coli O157:H7 (O157) survival mechanisms in the bovine rumen, we defined the growth characteristics and proteome of 0157 cultured in rumen fluid (RF; pH 6.0-7.2 and low volatile fatty acid content) obtained from rumen-fistulated cattle fed low protein content "maintenance diet" under diverse in vitro conditions.

Results: Bottom-up proteomics (LC-MS/MS) of whole cell-lysates of 0157 cultured under anaerobic conditions in filter-sterilized RF (fRF; devoid of normal ruminal microbiota) and nutrient-depleted and filtered RF (dRF) resulted in an anaerobic $\mathrm{O} 157$ fRF-and dRF-proteome comprising 35 proteins functionally associated with cell structure, motility, transport, metabolism and regulation, but interestingly, not with 0157 virulence. Shotgun proteomics-based analysis using isobaric tags for relative and absolute quantitation used to further study differential protein expression in unfiltered RF (URF; RF containing normal rumen microbial flora) complemented these results.

Conclusions: Our results indicate that in the rumen, the first anatomical compartment encountered by this human pathogen within the cattle gastrointestinal tract (GIT), 0157 initiates a program of specific gene expression that enables it to adapt to the in vivo environment, and successfully transit to its colonization sites in the bovine GIT. Further experiments in vitro using URF from animals fed different diets and with additional $\mathrm{O} 157$ strains, and in vivo using rumen-fistulated cattle will provide a comprehensive understanding of the adaptive mechanisms involved, and help direct evolution of novel modalities for blocking 0157 infection of cattle.
\end{abstract}

Keywords: O157, Rumen, LC-MS/MS, iTRAQ, Proteome, Growth-patterns

\section{Background}

Escherichia coli O157 (O157) have been implicated in several human outbreaks since their being established as foodborne pathogens in 1982; an estimated 63,153 illnesses, 2,138 hospitalizations and 20 deaths occur annually in the United States [1-4]. Human disease ranges from self-limiting watery diarrhea to debilitating bloody diarrhea that can advance into often fatal, extraintestinal, secondary sequelae in susceptible patients [3,4]. Cattle are the primary reservoirs for O157, with their rectoanal junction (RAJ) serving as the colonization site at which these human foodborne pathogens persist $[4,5]$. However, the first bovine gastrointestinal tract (GIT) compartment that $\mathrm{O} 157$ encounters is the rumen, where

\footnotetext{
* Correspondence: Indira.Kudva@ars.usda.gov

${ }^{1}$ Food Safety and Enteric Pathogens Research Unit, National Animal Disease Center, Agricultural Research Service, U.S. Department of Agriculture, Ames, lowa 50010, USA

Full list of author information is available at the end of the article
}

the dynamic environment of regurgitating food particles, bio-fermentation, changing $\mathrm{pH}$, and production of varying amounts of volatile fatty acids (VFA) poses challenges for O157 survival [6-8]. Studies thus far, have concentrated on the recovery of $\mathrm{O} 157$ from the rumen, the in vitro O157 growth dynamics in modified rumen fluid or media with additives to mimic the rumen environment, expression of select $\mathrm{O} 157$ genes under controlled $\mathrm{pH}$ and VFA conditions, dietary effects on bacterial survival, and effects of select flora/metabolite on the growth/survival of O157 in the rumen or rumen fluid [6-11]. Despite this, however, a comprehensive study of the mechanisms used by $\mathrm{O} 157$ to survive the rumen environment is yet to be undertaken. Hence, as an initial step, we determined the repertoire of $\mathrm{O} 157$ proteins (proteome) as expressed in vitro in harvested, rumen fluid (RF). We included RF of varying compositions (with and without normal flora, or depleted of nutrients essential for bacterial growth), with no additives, and used diverse culture conditions, to identify 
bacterial factors that may enable $\mathrm{O} 157$ adaptation to the rumen.

\section{Methods}

Bacterial strain, inoculum preparation and animals

Wild-type O157 strain 86-24 (Shiga toxin (Stx) 1-negative, Stx 2-positive; motile; clinical isolate) was used in this study [12]. Overnight culture of O157 in Luria-Bertani (LB) broth, grown at $39^{\circ} \mathrm{C}$ with aeration was used to prepare log-phase sub-cultures of the same in $50 \mathrm{ml}$ LB broth, under the same growth conditions. Bacteria harvested from the log-phase cultures at an $\mathrm{OD}_{600} 0.5-0.6$, washed and re-suspended in sterile $0.9 \%$ saline, were used to inoculate various rumen fluid (RF) or LB aliquots as described under 'Culture conditions and processing for proteomics'. All O157 cultures were confirmed serologically using latex agglutination kits (Remel Inc., Lenexa, KS). Two rumen-fistulated Holstein cows, routinely used as rumen fluid 'donors' at the National Animal Disease Center (NADC, Ames, IA) with approval from the NADC-Animal Care and Use Committee, were used in this study. Both animals, approximately 1 year of age, were fed the NADC Maintenance Diet (corn silage, grass hay, 520 pellets, protein supplements) at $25 \%$ fiber and $10 \%$ protein, with ad-lib access to water through out.

\section{Unfiltered (uRF), Filtered (fRF), and Depleted RF (dRF)}

Rumen fluid samples collected from the two animals (Samples A and B; Tables 1 and 2), on separate days, were used to prepare the RF-preparations for each experiment set (Experiment I and II). Two liters of RF was collected $2-3 \mathrm{hr}$ post-feeding to allow for rumination to occur, at each sampling time $[10,13]$. RF was strained through cheesecloth to remove large feed particles, and poured into collection flasks; $\mathrm{pH}$ was recorded on site

\section{Table 1 Biochemical characteristics of rumen fluid used to analyze growth patterns of 0157 strain $86-24$ in Experiment I}

\begin{tabular}{cccccc}
\hline $\begin{array}{c}\text { Sample } \\
\text { analysis }\end{array}$ & \multicolumn{2}{c}{ Depleted rumen fluid } & & \multicolumn{2}{c}{ Filtered rumen fluid } \\
\cline { 2 - 3 } \cline { 5 - 6 } & Sample A & Sample B & & Sample A & Sample B \\
\hline $\mathrm{pH}^{1}$ & 7.9 & 7.6 & 7.6 & 7.7 \\
& \multicolumn{2}{c}{ Volatile Fatty } & Acids $(\mu \mathrm{m} / \mathrm{ml}$; VFA) & \\
Total VFA & 324 & 207 & 211 & 157 \\
Acetic acid & 201 & 142 & & 144 & 112 \\
& $(62 \%)^{2}$ & $(69 \%)$ & & $(68 \%)$ & $(71 \%)$ \\
Propionic acid & 41 & 28 & 31 & 23 \\
& $(13 \%)$ & $(14 \%)$ & $(15 \%)$ & $(15 \%)$ \\
Butyric acid & 43 & 20 & & 16 & 10 \\
& $(13 \%)$ & $(10 \%)$ & & $(8 \%)$ & $(6 \%)$ \\
\hline
\end{tabular}

${ }^{1} \mathrm{pH}$, post-depletion and/or post-filtration of the depleted and filtered rumen fluid samples, respectively.

${ }^{2}$ Percent individual volatile fatty acid of the total is shown in parenthesis. and an aliquot frozen at $-80^{\circ} \mathrm{C}$ for volatile fatty acid (VFA) analysis. Approximately $500 \mathrm{ml}$ of the strained RF was stored as the unfiltered RF (uRF) at $4^{\circ} \mathrm{C}$.

One half of the remaining strained RF was processed as follows to generate filtered RF (fRF). The strained RF was centrifuged at $27,000 \times \mathrm{g}$ for $30 \mathrm{mins}$ at $18^{\circ} \mathrm{C}$, at least 3 times, to remove particulate matter and pressure filtered using a $0.5 \mu$ pre-filter and a $0.2 \mu$ filter in tandem (Pall Corporation, Port Washington, NY). The fRF was collected into sterile bottles and stored at $4^{\circ} \mathrm{C}$ after recording the $\mathrm{pH}$ and freezing an aliquot for VFA analysis.

To prepare $\mathrm{dRF}$, the other half of the remaining strained RF was first subjected to depletion, a process that involves exhaustion of residual nutrients in the $R F$ by exploiting metabolic activities of the resident microflora, prior to the centrifugation-filtration steps. Specifically, the depletion process was initiated by adjusting the strained RF pH to 6.8-7.0, and incubating it under anaerobic conditions, at $39^{\circ} \mathrm{C}$ for four days. The strained RF was held in flasks fitted with stoppers bearing valves to release the fermentation gases throughout the incubation, following which the depleted RF was centrifuged and filtered as described above. This depletion protocol was adapted from previously described methods with no extraneous substrates added to the RF prior to depletion $[11,14]$. The $\mathrm{pH}$ of the resultant filter-sterilized dRF was recorded and aliquots set aside for VFA analysis prior to storage at $4^{\circ} \mathrm{C}$ in sterile bottles.

\section{$\mathrm{pH}$ and volatile fatty acids (VFA) analysis}

Initial rumen fluid $\mathrm{pH}$ measurements were taken during collection by using a portable $\mathrm{pH}$ meter (Thermo Fisher Scientific Inc., Waltham, MA) $[8,11]$. Subsequently, the $\mathrm{pH}$ meter or $\mathrm{pH}$ paper was used $(\mathrm{pH}$ range 5.0-8.0; Micro Essential Laboratory Inc., Brooklyn, NY), to record $\mathrm{pH}$ of the processed RF and media. VFA concentrations in rumen fluid and its preparations were determined by capillary gas chromatography of their butyl esters, as described previously [15,16], on an Agilent $6890 \mathrm{~N}$ gas chromatograph (Agilent Technologies, Inc., Santa Clara, CA).

\section{Culture conditions, and processing for proteomics}

RF preparations from Samples A and B were analyzed separately per experiment set, and each analysis in turn was conducted in duplicate. In Experiment I, $5 \mathrm{ml} \mathrm{LB}$, $\mathrm{dRF}$, or fRF media were aliquoted separately into 85 , $16 \times 150 \mathrm{~mm}$ tubes. Of these, five tubes per media were used as uninoculated controls. The remaining 80 tubes were inoculated with $\mathrm{O} 157$. To create anaerobic culture conditions, half of these tubes were transferred into the anaerobic Coy Chamber for 72 hrs, sealed and inoculated within the chamber and then removed. The logphase $\mathrm{O} 157$ culture, re-suspended in $0.9 \%$ saline was 
Table 2 Biochemical characteristics of rumen fluid used to analyze growth patterns of 0157 strain 86-24 in Experiment II

\begin{tabular}{|c|c|c|c|c|c|c|}
\hline \multirow{2}{*}{$\begin{array}{l}\text { Sample } \\
\text { analysis }\end{array}$} & \multicolumn{2}{|c|}{ Depleted rumen fluid } & \multicolumn{2}{|c|}{ Filtered rumen fluid } & \multicolumn{2}{|c|}{ Unfiltered rumen fluid } \\
\hline & Sample A & Sample B & Sample A & Sample B & Sample A & Sample B \\
\hline $\mathrm{pH}^{1}$ & 7.6 & 7.4 & 7.7 & 7.2 & 6.4 & 6.7 \\
\hline \multicolumn{7}{|c|}{ Volatile Fatty Acids ( $\mu \mathrm{m} / \mathrm{ml}$; VFA) } \\
\hline Total & 203 & 205 & 144 & 153 & 210 & 165 \\
\hline \multirow[t]{2}{*}{ Acetic acid } & 139 & 140 & 103 & 110 & 141 & 104 \\
\hline & $(68 \%)^{2}$ & $(68 \%)$ & (72\%) & $(72 \%)$ & $(67 \%)$ & $(63 \%)$ \\
\hline \multirow[t]{2}{*}{ Propionic acid } & 28 & 28 & 21 & 23 & 32 & 30 \\
\hline & $(14 \%)$ & $(14 \%)$ & $(13 \%)$ & $(15 \%)$ & $(15 \%)$ & $(18 \%)$ \\
\hline \multirow[t]{2}{*}{ Butyric acid } & 19 & 19 & 9 & 10 & 20 & 17 \\
\hline & $(9 \%)$ & $(9 \%)$ & $(6 \%)$ & $(7 \%)$ & $(10 \%)$ & $(10 \%)$ \\
\hline
\end{tabular}

${ }^{1} \mathrm{pH}$, post-depletion and/or post-filtration of the depleted and filtered rumen fluid samples, respectively.

${ }^{2}$ Percent individual volatile fatty acid of the total is shown in parenthesis.

inoculated to a starting $\mathrm{OD}_{600} 0.05-0.06$, into all the 80 tubes, which were then incubated at $39^{\circ} \mathrm{C}$ with shaking, along with the uninoculated control tubes. O157 was grown to an $\mathrm{OD}_{600}$ of 0.8-1.0, before harvesting cells from each tube by centrifugation at 7,000 rpm, $15 \mathrm{~min}$ at $4^{\circ} \mathrm{C}$. Bacterial cells from like media, whether derived from RF-samples A or B, were pooled together and washed three times with an equal volume of ice-cold sterile phosphate buffered saline (PBS; $\mathrm{pH}$ 7.4), and processed to obtain cell lysate and pellet fractions for bottom-up proteomic analysis [17].

In Experiment II, uRF was included to the media (LB, dRF, fRF) being evaluated and aliquoted as described above. However, the $\mathrm{O} 157$ inoculum diluted in saline to the starting $\mathrm{OD}_{600} 0.05-0.06$ was placed in sterile dialysis tubing (Spectra/Por Type F, PVDF: 80,000 kDa cut off; Serva Electrophoresis, Heidelberg, Germany) and suspended within the uRF containing tubes [18]. This was to ease the recovery of $\mathrm{O} 157$ from the complex uRF milieu and the colony counts recovered from the tubings matched those obtained by magnetic recovery of O157 from directly inoculated uRF (data not shown). O157innoculated LB, dRF, fRF, and URF were incubated for $48 \mathrm{~h}$, anaerobically, before harvesting cells and processing for proteomic analysis [17] using iTRAQ. For this experiment, bacterial cells from like media were pooled together but kept separate between preparations derived from RF-samples A and B. The culture conditions used in Experiment II correlated with ruminal conditions and feed turnover rates [19-21]. In both experiments, $\mathrm{OD}_{600}$ of each tube was recorded relative to uninoculated control tubes, centrifuged at $10,000 \mathrm{rpm}$ for $10 \mathrm{~min}$ to remove any sediments or particulate matter which could interfere with the spectrophotometer reading. In addition, $\mathrm{pH}$, and colony counts (on LB agar) were determined from the five uninoculated and ten inoculated tubes at different time points, for comparison.
Bottom-up proteomics using liquid chromatography tandem mass spectrometry (LC-MS/MS)

This proteomic analysis was done at the Proteomics Division, ICBR, University of Florida, Gainesville, Florida. O157 cell pellet and lysate fractions from Experiment I (LB, dRF, fRF) were concentrated using spin filters (MW cutoff 5000 Daltons), and digested with trypsin prior to tandem mass spectrometry (MS/MS) as described previously [17]. The enzymatically-digested samples were injected onto a capillary trap (LC Packings PepMap) and desalted for $5 \mathrm{~min}$ with a flow rate of $3 \mu \mathrm{l} / \mathrm{min}$ of $0.1 \% \mathrm{v} / \mathrm{v}$ acetic acid. The samples were loaded onto an LC Packing ${ }^{\bullet}$ C18 Pep Map nanoflow HPLC column. The elution gradient of the HPLC column started at $3 \%$ solvent B, $97 \%$ solvent A and finished at $60 \%$ solvent B, 40\% solvent A for 95 min for protein identification.

Solvent A consisted of $0.1 \% \mathrm{v} / \mathrm{v}$ acetic acid, $3 \% \mathrm{v} / \mathrm{v}$ acetonitrile $(\mathrm{ACN})$, and $96.9 \% \mathrm{v} / \mathrm{v} \mathrm{H}_{2} \mathrm{O}$. Solvent B consisted of $0.1 \% \mathrm{v} / \mathrm{v}$ acetic acid, $96.9 \% \mathrm{v} / \mathrm{v} \mathrm{ACN}$, and $3 \% \mathrm{v} / \mathrm{v} \mathrm{H}_{2} \mathrm{O}$. LC-MS/MS analysis was carried out on a hybrid quadrupole-TOF mass spectrometer (QSTAR elite, Applied Biosystems, Framingham, MA). The focusing potential and ion spray voltage was set to $225 \mathrm{~V}$ and $2400 \mathrm{~V}$, respectively. The information-dependent acquisition (IDA) mode of operation was employed in which a survey scan from m/z 400-1800 was acquired followed by collision-induced dissociation (CID) of the four most intense ions. Survey and MS/MS spectra for each IDA cycle were accumulated for 1 and $3 \mathrm{~s}$, respectively.

Tandem mass spectra were extracted by ABI Analyst version 2.0. All MS/MS samples were analyzed using Mascot (Matrix Science, London, UK; version 2.2.2). Mascot was set up to search NCBI with taxonomy Bacteria database assuming the digestion enzyme trypsin. Mascot was searched with a fragment ion mass tolerance of $0.50 \mathrm{Da}$ and a parent ion tolerance of 0.50 Da. Iodoacetamide derivative of Cys, deamidation of Asn and Gln, 
oxidation of Met, were specified in Mascot as variable modifications. Scaffold (version Scaffold-03-3-2, Proteome Software Inc., Portland, OR) was used to validate MS/MS based peptide and protein identifications. Peptide identifications were accepted if they could be established at greater than $95.0 \%$ probability as specified by the Peptide Prophet algorithm [22]. Protein identifications were accepted if they could be established at greater than $99.0 \%$ probability and contained at least 2 identified unique peptides. Proteins with single peptide hits were included if they exhibited high confidence based on low false discovery rates [23]. Relative protein abundance was estimated using the normailized total spectral counts [24]. Protein probabilities were assigned using the Protein Prophet algorithm [25]. Proteins that contained similar peptides and could not be differentiated based on MS/MS analysis alone were grouped to satisfy the principles of parsimony.

\section{Quantitative proteomics using isobaric tags for relative and absolute quantification (iTRAQ)}

O157 cell pellet and lysate fractions from Experiment II (LB, dRF, fRF, uRF; cultured $48 \mathrm{~h}$, anaerobically) were analyzed by iTRAQ. Samples were processed, trypsin digested, and labeled with various iTRAQ reagents as described earlier [26], in accordance with the manufacture's instructions for the iTRAQ 4-plex kit (AmineModifying Labeling Reagents for Multiplexed Relative and Absolute Protein Quantitation, Applied Biosystems, Foster City CA). Labeled peptides were combined, dried in one tube, and held at $-80^{\circ} \mathrm{C}$ until use. A modification of the previously used protocol was used to analyze these labeled peptides that were resuspended in mobile phase A (72 mM triethlyamine in $\mathrm{H} 2 \mathrm{O}, \mathrm{pH} 10$ with acetic acid) at a concentration of $200 \mu \mathrm{g} / \mu \mathrm{l}$ and incubated for 1 hour in a sonic-water bath at RT. $100 \mu \mathrm{g}$ of sample was injected into a Waters $1525 \mu$ Binary HPLC (Waters Corporation, Milford, MA) with a Waters XBridge C18, 3.5um, $1 \times 100 \mathrm{~mm}$ column in mobile phase A and ran isocratically for 6 minutes. The gradient consisted of, $0-20 \%$ mobile phase $\mathrm{B}(72 \mathrm{mM}$ triethlyamine in $\mathrm{ACN}$, $52 \mathrm{mM}$ acetic acid), over 34 minutes; $20-40 \%$ over 20 minutes; and finally $40-100 \%$ over 2 minutes, at a flow rate of $100 \mu \mathrm{l} /$ minute throughout the entire gradient [27]. Two-minute fractions were collected, dried in a vacuum centrifuge, and resuspended in nano-HPLC buffer A (95\% $\mathrm{H}_{2} \mathrm{O}: 5 \% \mathrm{ACN}$ and $0.1 \%$ formic acid). Based on previous experience we combined, 3 fractions before and after, the fractions that contained the majority of the eluted peptides.

Fractions from the first dimension chromatography were injected on a second dimension of chromatography using a Proxeon Easy-nLC (Thermo Fisher Scientific, West Palm Beach, FL) connected to the mass spectrometer. The second dimension chromatography used a trapping column (Proxeon Easy-Column, 2 cm, ID $100 \mu \mathrm{m}$, 5um, $120 \mathrm{~A}, \mathrm{C} 18$ ) and an analytical column (Proxeon EasyColumn, $10 \mathrm{~cm}$, ID $75 \mu \mathrm{m}, 3 \mu \mathrm{m}, 120 \mathrm{~A}, \mathrm{C} 18)$. The gradient using a mobile phase A (95\% H2O: $5 \%$ acetonitrile and $0.1 \%$ formic acid) and mobile phase B (5\% $\mathrm{H} 2 \mathrm{O}$ : $95 \%$ acetonitrile and $0.1 \%$ formic acid). The gradient was, $0 \% \mathrm{~B}$ for 3 minutes, $0 \%-8 \%$ B from 3-5 minutes, $8-18 \% \mathrm{~B}$ from 5-85 minutes, 18-30\% B from 85-100 minutes, $30-90 \%$ B from 100-105 minutes, and held at 90\% B from 105-120 minutes at continuous flow rate throughout the gradient of $300 \mathrm{nl} / \mathrm{min}$. The analytical column was connected to a PicoTip Emitter (New Objectives, Woburn, MA; FS360-75-15-N-20) and together attached to a LTQ OrbiTrap Velos Pro (Thermo Fisher Scientific, West Palm Beach, FL) mass spectrometer using the Proxeon Nanospray Flex Ion Source. The capillary temperature was set at $275^{\circ} \mathrm{C}$ and spray voltage was $2.9 \mathrm{kV}$. The mass spectrometer was used in a data dependent method. In MS mode, the instrument was set to scan $300-2000 \mathrm{~m} / \mathrm{z}$ with a resolution of 30,000 FWHM. A minimal signal of 20,000 could trigger tandem MS and 10 consecutive MS/MS were possible. High-energy collision-induced dissociation (HCD) was used to resolve the iTRAQ reporter ions, 113-117. The normalized collision energy was set to 35 and repeat mass exclusion was set to 120 seconds.

Tandem mass spectra were extracted and charge state deconvoluted by Proteome Discoverer version 1.4. Charge state deconvolution and deisotoping was not performed. All MS/MS samples were analyzed using Mascot, Sequest (XCorr Only; Thermo Fisher Scientific, San Jose, CA, USA; version 1.3.0.339) and X! Tandem (GPM.org; version CYCLONE (2010.12.01.1)) assuming digestion with trypsin. A custom E. coli database was generated by combining the fasta files from uniprot.org from the following E. coli strains: 12009/EHEC, 2009EL-2050, 2009EL2071, 2011C-3493, 11128/EHEC, O157:H7, EC4115/ EHEC, TW14359/EHEC, and 11368/EHEC. This E. coli fasta file consists of 47,819 entries and was generated in May 2013. Mascot, Sequest (XCorr Only) and X! Tandem were searched with a fragment ion mass tolerance of $0.100 \mathrm{Da}$ and a parent ion tolerance of 10.0 PPM; carbamidomethyl of cysteine and iTRAQ4plex of lysine and the n-terminus were specified as fixed modifications while deamidation of asparagine and glutamine, oxidation of methionine and iTRAQ4plex of tyrosine were specified as variable modifications. Scaffold (version Scaffold_4.0.6) was used to validate MS/MS based peptide and protein identifications, as described above for 'Bottom-up Proteomics'. The O157-proteome as expressed in LB was used as the reference against which all the other O157-proteomes were compared. Two biological replicate samples (Sample A and B), corresponding to the duplicate experiments described under 'Culture conditions, and 
processing for proteomics' above, were analyzed separately. In addition, each sample was analyzed twice (Run A and Run B; technical replicates) to cover the entire spectra of proteins in these samples. Only proteins that were consistently identified were selected for analysis.

\section{Statistics and bioinformatics}

The Student t-Test (two-tailed) was used to evaluate differences between the means of the $\mathrm{O} 157$ optical densities and viable counts recovered from the different cultures and a values of $p<0.05$ was considered significant. Putative functions were determined by querying the Conserved Domain Database (CDD) at http://www.ncbi.nlm.nih.gov/ Structure/cdd/wrpsb.cgi, and associated metabolic pathways were determined using the KEGG pathway database at http://www.genome.jp/kegg/pathway.html. Cellular and sub-cellular locations of proteins were determined as described previously [17].

\section{Results}

\section{$\mathrm{pH}$ and VFA content}

The $\mathrm{pH}$ and VFA concentrations were comparable amongst all rumen fluid samples, indicating consistency in maintenance diet being fed and the ruminal chemistry between the two animals enrolled in the study (Tables 1 and 2). The $\mathrm{pH}$ of the uRF ranged from 6.4-6.7 at collection [28-31] but attained a more neutral $\mathrm{pH}$ after filtering, as seen with dRF ( $\mathrm{pH} 7.4-7.9)$ and fRF ( $\mathrm{pH}, 7.2-7.7)$ in both experiments (Tables 1 and 2). Concentrations of three VFAs, acetate, propionate and butyrate, were closely analyzed as these vary the most with changes in the forage versus starch compositions of the feed, and are of relevance to both host and bacterial growth. Consistent with the $25 \%$ forage and $10 \%$ protein diet that these cattle were being fed, the RF comprised a higher percentage of acetate [28-31]. Acetate ranged from 72-62\%, compared to the $13-18 \%$ propionate and $6-13 \%$ butyrate concentrations across the uRF, dRF and fRF samples in both experiments, irrespective of procedures used to prepare $\mathrm{dRF}$ and $\mathrm{fRF}$ (Tables 1 and 2). LB broth ( $\mathrm{pH} 7.0-7.2)$ did not contain added VFAs.

\section{7 growth characteristics}

Log phase O157 cultures, set up for the two experiments, were at $0.5-0.6 \mathrm{OD}_{600}$, respectively, with viable counts around $1 \times 10^{8} \mathrm{cfu} / \mathrm{ml}$. Hence, when each medium was inoculated to a starting $0.05-0.06 \mathrm{OD}_{600}$, the corresponding $\mathrm{O} 157$ counts were at $\sim 1-5 \times 10^{7} \mathrm{cfu} / \mathrm{ml}$. In both experiments, $\mathrm{O} 157$ grew to an $\mathrm{OD}_{600}$ of 1.0 within $2 \mathrm{~h}$ in LB media, aerobically and anaerobically as anticipated, with an increase in viable count to $4 \times 10^{8} \mathrm{cfu} / \mathrm{ml}$ and the final culture $\mathrm{pH}$ at 6.0-6.2. However, significant differences were observed between aerobic and anaerobic growth patterns of $\mathrm{O} 157$ when cultured in $\mathrm{dRF}, \mathrm{fRF}$ and uRF preparations.

In Experiment I, O157 cultured in dRF and fRF achieved an average $\mathrm{OD}_{600}$ of 0.6-1.0 in $48 \mathrm{~h}$ aerobically, but remained at a low $\mathrm{OD}_{600}$ of $\leq 0.2$ anaerobically, even after 14 days of incubation. Irrespective of the ODs, viable $\mathrm{O} 157$ was recovered from all cultures, but the viable counts at $10^{6}(\mathrm{dRF})-2 \times 10^{7}(\mathrm{fRF}) \mathrm{cfu} / \mathrm{ml}$ aerobically, and at $10^{5}(\mathrm{dRF})-2 \times 10^{5}(\mathrm{fRF}) \mathrm{cfu} / \mathrm{ml}$ anaerobically (data not shown) appeared to be static or decreasing. The $\mathrm{pH}$ for $\mathrm{dRF}$ and $\mathrm{fRF}$ cultures at the end of incubation was around 7.7 (aerobic)-7.3 (anaerobic). Similar O157 growth results were observed upon anaerobic culture for $48 \mathrm{~h}$ in $\mathrm{dRF}, \mathrm{fRF}$ and $\mathrm{uRF}$, in Experiment II (Figure 1), with the $\mathrm{pH}$ for URF cultures being 6.8 at end of incubation. This was despite these media being prepared with RF from a separate animal and a shorter anaerobic incubation period than in the first experiment, thereby verifying the observations made initially. Here, the cultures reached an average $\mathrm{OD}_{600}$ of 0.97 (LB), 0.03 (dRF), 0.04 (fRF) and $\sim 0.03$ (uRF) in $48 \mathrm{~h}$, with $\mathrm{O} 157$ viable counts of $2 \times 10^{8} \mathrm{cfu} / \mathrm{ml}(\mathrm{LB}), 4 \times 10^{5} \mathrm{cfu} / \mathrm{ml}(\mathrm{dRF}), 3 \times 10^{6} \mathrm{cfu} / \mathrm{ml}$ (fRF) and $1 \times 10^{6} \mathrm{cfu} / \mathrm{ml}(\mathrm{uRF})$, respectively.

Significant differences were observed among the optical densities and viable counts of LB cultures versus RF-preparation cultures, under all growth conditions. However, differences between the RF-preparations were not always significant (Figure 1). For instance, in Experiment II, the $p$ values for the $\mathrm{O} 157$ viable counts were: LB: dRF, $p=0.0379$; LB: fRF, $p=0.0385 ; \mathrm{LB}: \mathrm{uRF}, p=0.0381$, dRF: fRF, $p=0.0121$ and fRF: uRF, $p=0.0655$; dRF: uRF, $p=0.1077$.

\section{Proteomics analysis \\ (i) Bottom-up}

LC-MS/MS analysis of the O157 cell pellet and lysate fractions generated in Experiment I provided insights into the proteins being expressed by $\mathrm{O} 157$ in different media, under different growth conditions and at extended incubation time points. A total of 585 protein (2284 spectra) hits were identified by setting minimum characteristics for the identification confidence. However, of these only $218 \mathrm{O} 157$ proteins matched a higher threshold cut off, with $90 \%$ protein- $80 \%$ peptide probability in the Scaffold Viewer, and hence, were selected for analysis. The 2180157 proteins were differentially expressed: 90 only under aerobic conditions, 37 only under anaerobic conditions and 91 under both conditions (data not shown), accounting for fewer proteins under anaerobic conditions. Interestingly, none of the O157 proteins expressed aerobically or anaerobically in either media were associated with direct virulence (e.g., the Locus of Enterocyte Effacement [LEE]-encoded proteins or Shiga toxins) but were primarily associated with 

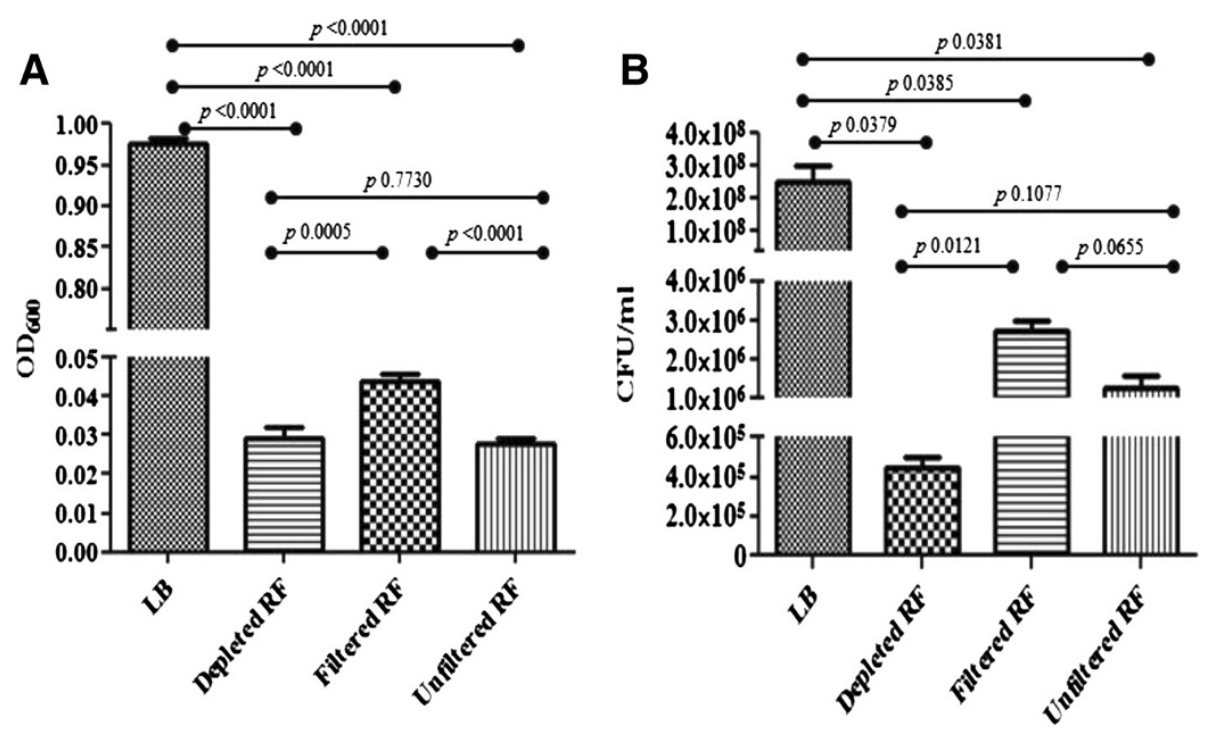

Figure 1 Growth characteristics of 0157 in Experiment II, following anaerobic incubation for $\mathbf{4 8}$ h, in LB and RF-preparations. Optical densities $\left(\mathrm{OD}_{600}\right)$ and viable counts (colony forming units $\left.[\mathrm{cfu}] / \mathrm{ml}\right)$, with the standard error of means, are shown in graph $\mathbf{A}$ and $\mathbf{B}$, respectively. The $p$ values shown on the graphs were calculated using the Student t-Test (significant, $p<0.05$ ).

sequences homologous to other $E$. coli genomes (Backbone) (Additional file 1: Table S1). Considering that the rumen is an anaerobic microbiome, the $128 / 218 \mathrm{O} 157$ proteins expressed anaerobically were examined in greater detail. These proteins were either unique to growth in LB (93/128), dRF (2/128), fRF (10/128) or, expressed in more than one media (14/128 in LB/dRF/fRF, 9/128 in dRF/fRF) (Figure 2). Specifically, the 35 proteins expressed anaerobically in fRF and dRF (unique and shared combined), were functionally associated with the osmotic adaptation pathway (OsmE), anaerobic respiration and oxidative stress pathway (YggE, MoaB, DmsB, FdoH), heat stress response (HchA), carbon starvation response (Slp), energy metabolism and biosynthetic pathways (glycolytic/ gluconeogenesis pathway, amino acid biosynthesis: AldoC, Crr, AnsB, PykF, Eno, GpmA, GadpH, CysK, Ttc, AhpC, YhcB), chaperones (DnaK, GroEL, HchA), transport (LamB, ManX, FadL, RbsB), outer membrane proteins/ porins/channel (OmpC, TolC, YdeN, Slp, OmpA), tellurite resistance (TerD), lysozyme inhibitor (Ivy), chemotaxis (GgbP), and motility (FliC) (Table 3; Additional file 1: Table S1).

\section{(ii) iTRAQ}

To more closely examine and quantify O157 protein expression in the bovine rumen, especially in the $u R F$, the anaerobic O157-proteome expressed in LB, dRF, fRF and $\mathrm{uRF}$ after $48 \mathrm{~h}$ incubation was compared using iTRAQ, in Experiment II. Data generated in two runs for each biological replicate was condensed to create a single comprehensive file per sample, and the files for the two biological replicate samples compared (Additional file 2:
Table S2) to identify unambiguous proteins. Using the anaerobic O157-proteome expressed in LB as the reference, a total of $394 \mathrm{O} 157$ proteins that were either differentially or similarly expressed in dRF, fRF, and $\mathrm{uRF}$ were identified (Figure 3, Additional file 2: Table S2). Of the cumulative $35 \mathrm{O} 157$ proteins expressed anaerobically in $\mathrm{dRF}$ and $\mathrm{fRF}$, and identified via Bottom-up proteomics, 10 were not identified using ITRAQ in the second experiment (Table 3 ). Overall, only 134 proteins were common

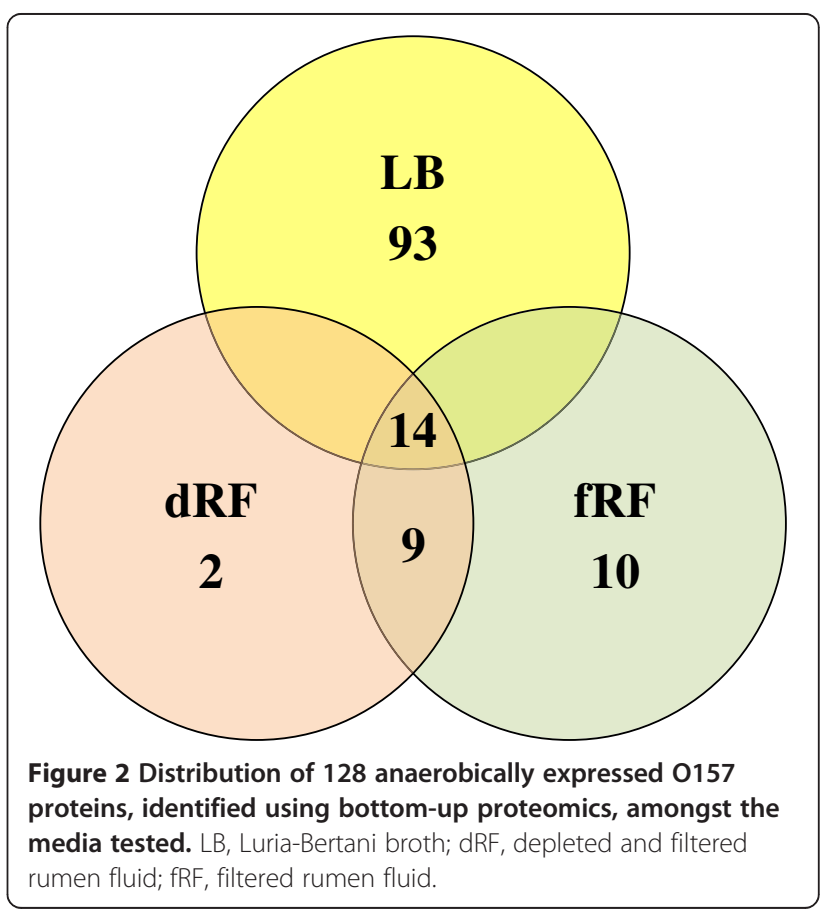


Table 3 0157-proteome expressed under anaerobic conditions in dRF and fRF in Experiment I

\begin{tabular}{|c|c|c|c|c|}
\hline \multirow[t]{2}{*}{ Protein/Function/Pathway; Name } & \multirow[t]{2}{*}{$\begin{array}{l}\text { Accession } \\
\text { Number }\end{array}$} & \multirow[t]{2}{*}{$\begin{array}{c}\text { Molecular } \\
\text { Weight }(\mathrm{kDa})^{1}\end{array}$} & \multicolumn{2}{|c|}{$\begin{array}{c}\text { Number of Peptides } \\
\text { (Relative Abundance) }\end{array}$} \\
\hline & & & dRF & fRF \\
\hline 2,3-bisphosphoglycerate-dependent phosphoglycerate mutase; GpmA & gi|157155502 & $29 \mathrm{kDa}$ & $1(6)$ & $1(4)$ \\
\hline 3-isopropylmalate dehydrogenase/Amino acid Biosynthesis; $\mathbf{T t C}^{3}$ & gi|170684236 & $40 \mathrm{kDa}$ & $1(6)$ & $1(4)$ \\
\hline Alkyl hydroperoxide reductase protein C/Energy; AhpC & gi|15800320 & $21 \mathrm{kDa}$ & 0 & $1(4)$ \\
\hline Anaerobic dimethyl sulfoxide reductase/Anaerobic growth/Oxidative Stress; DmsB & gi|145756 & $23 \mathrm{kDa}$ & $1(6)$ & $1(4)$ \\
\hline Chain A, Crystal Structure Of The Long-Chain Fatty Acid Transporter/Transport; Fadl & gi|203282230 & $47 \mathrm{kDa}$ & $1(6)$ & $1(4)$ \\
\hline Chain A, Crystal Structure Of Ggbp. Glucose-galactose binding protein/Chemotaxis, Transport; Ggbp ${ }^{3}$ & gi|126030485 & $33 \mathrm{kDa}$ & 0 & $1(4)$ \\
\hline Chain A, Structure Of Ivy/ Lysozyme inhibitor; Ivy & gi|29726212 & $15 \mathrm{kDa}$ & $1(6)$ & $1(4)$ \\
\hline Chaperone protein, stabilizes proteins under heat stress/Heat Stress Related; HchA & gi|15802400 & $31 \mathrm{kDa}$ & 0 & $1(4)$ \\
\hline Chaperonin, type 1 protein/Protein folding/Transport; GroEL ${ }^{3}$ & gi|15834378 & $57 \mathrm{kDa}$ & $3(18)$ & $3(11)$ \\
\hline Cysteine synthase/Amino acid transport and Metabolism; CysK & gi|145686 & $35 \mathrm{kDa}$ & $1(6)$ & $1(4)$ \\
\hline Cytochrome d ubiquinol oxidase subunit III/Oxidative phosphorylation/Energy; $\mathbf{Y h C B}^{3}$ & gi|157148804 & $15 \mathrm{kDa}$ & 0 & $1(4)$ \\
\hline D-ribose transporter subunit B/Transport; RbsB & gi|110644091 & $31 \mathrm{kDa}$ & $1(6)$ & 0 \\
\hline DNA-binding transcriptional activator/Osmotically-inducible lipoprotein E; OsmE & gi|15802150 & $12 \mathrm{kDa}$ & $2(18)$ & $2(7)$ \\
\hline DNA-directed RNA polymerase subunit alpha/Transcription; RpoA & gi|123444073 & $37 \mathrm{kDa}$ & 0 & $1(4)$ \\
\hline Flagellin/Flagellar assembly/Motility; Flic & gi|15802358 & $60 \mathrm{kDa}$ & $3(24)$ & $4(19)$ \\
\hline Formate dehydrogenase-O, iron-sulfur subunit, energy metabolism/Anaerobic Respiration, Glyoxylate \& Dicarboxylate Metabolism; FdoH & gi|15804482 & $33 \mathrm{kDa}$ & 0 & $1(4)$ \\
\hline Fructose-bisphosphate aldolase/Glycolysis, Gluconeogenesis, Amino acid Biosynthesis; AldoC & gi|161984958 & $38 \mathrm{kDa}$ & $3(24)$ & $4(19)$ \\
\hline Glucose-specific PTS system component, phosphorylation/Transport; Crr & gi|15802950 & $18 \mathrm{kDa}$ & 0 & $1(4)$ \\
\hline Glyceraldehyde 3-Phosphate Dehydrogenase; GadpH ${ }^{3}$ & gi|1421424 & $35 \mathrm{kDa}$ & $2(12)$ & $1(4)$ \\
\hline Hypothetical protein CKO_00658/ Uncharacterized; DedA ${ }^{3}$ & gi|157144929 & $21 \mathrm{kDa}$ & 0 & $1(4)$ \\
\hline Hypothetical protein EcE24377A_0553/Glyoxylate Utilization; GIxB & gi|157157046 & $29 \mathrm{kDa}$ & $1(6)$ & 0 \\
\hline Hypothetical protein ECP_2911/Oxidative Stress; YggE & gi|110643066 & $25 \mathrm{kDa}$ & 0 & $2(7)$ \\
\hline L-asparaginase II, induced by anaerobiosis/Nitrogen and Amino acid Metabolism; AnsB & gi|157157301 & $37 \mathrm{kDa}$ & 0 & $4(15)$ \\
\hline Maltoporin/Receptor for lambda phage/Transport; LamB ${ }^{3}$ & gi|110644375 & $50 \mathrm{kDa}$ & $1(6)$ & $1(4)$ \\
\hline Molecular chaperone/Protein folding/Transport; DnaK & gi|157159481 & $69 \mathrm{kDa}$ & $7(42)$ & $4(15)$ \\
\hline Molybdopterin biosynthesis protein B/Cofactor Biosynthesis/ Oxidative Stress; MoaB & gi|15800533 & $19 \mathrm{kDa}$ & 0 & $1(4)$ \\
\hline Outer membrane channel protein, efflux of hydrophobic molecules/Transport; TolC & gi|110643281 & $54 \mathrm{kDa}$ & 0 & $2(7)$ \\
\hline Outer membrane porin protein $\mathrm{C} /$ Tranport of small molecules/Osmotic; OmpC ${ }^{3}$ & gi|15802768 & $41 \mathrm{kDa}$ & $1(6)$ & $5(22)$ \\
\hline Outer membrane protein II, porin, receptor, integrity/Membrane Stability; OmpA & gi|146983 & $26 \mathrm{kDa}$ & $2(12)$ & $3(11)$ \\
\hline Outer membrane protein induced after carbon starvation, stationary phase, environmental stress/ Membrane stability; Slp & gi|1 10807343 & $27 \mathrm{kDa}$ & 0 & $1(4)$ \\
\hline Phosphopyruvate hydratase: enolase/Glycolysis, Gluconeogenesis; Eno $^{3}$ & gi|15832893 & $46 \mathrm{kDa}$ & 0 & $1(4)$ \\
\hline
\end{tabular}


Table 3 0157-proteome expressed under anaerobic conditions in dRF and fRF in Experiment I (Continued)

PTS system, mannose-specific IIAB component/phosphotransferase/Transport; ManX

gi|110641934

$35 \mathrm{kDa}$

gi|110641672

$63 \mathrm{kDa}$

Putive sulfatase//norganic ion transport and metabolism//ransport; Yde

gi|110805653

$59 \mathrm{kDa}$

Tellurium resistance protein/Stress related; TerD

gi|135596

$20 \mathrm{kDa}$

KDa, Kilodalton.

${ }^{3}$ Proteins not identified in Experiment II (see Table 4). 


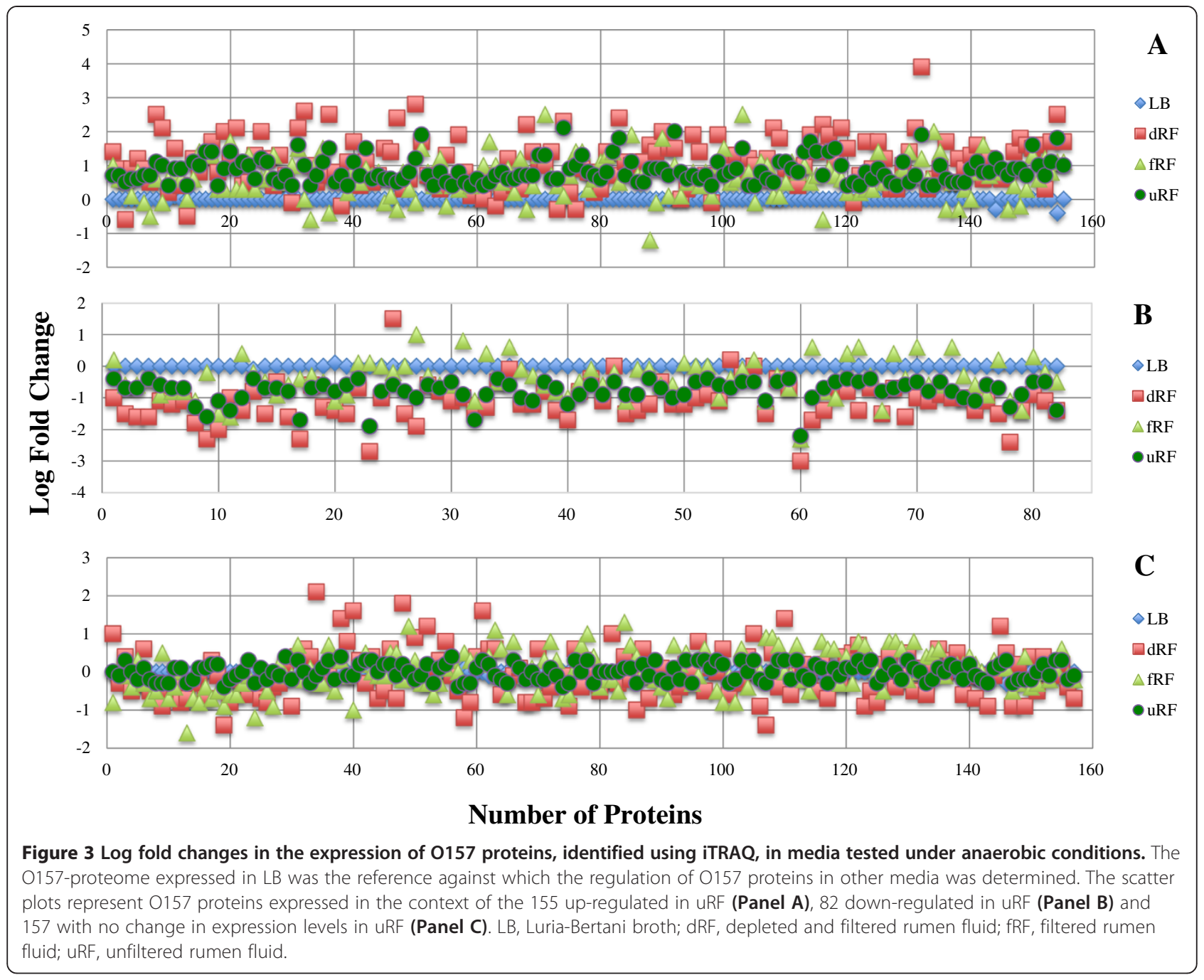

to the results of the two experiments, indicative of incubation-time related differences in the number and type of proteins expressed. Differentially expressed O157 proteins in the iTRAQ dataset distributed as 298/394 in dRF (169, up-regulated, 129, down-regulated), 241/394 in fRF (162, up-regulated, 79, down-regulated) and 237/394 in uRF (155, up-regulated, 82, down-regulated) (Table 4). Interestingly, similar expression patterns were observed between O157 proteins expressed in dRF and URF; 90\% of dRF-differentially regulated and 71\% dRF-no change proteins were similarly expressed in uRF. This may have been due to shared growth conditions (nutrient limitation)/ signals in these two media. The competing microflora in URF may have decreased nutrients in that media.

As observed with the Bottom-up proteomics results, none of the well-established $\mathrm{O} 157$ virulence factors were identified in either media after $48 \mathrm{~h}$ of anaerobic incubation (Additional file 2: Table S2). Specifically, the 155 up-regulated (Table 4), uRF-O157 proteins could be functionally associated with osmotic adaptation (MdoG,
CreC, OsmE, YjbJ), oxidative stress pathway (KatG, DmsA_ynfE, DmsA_ynfF, YggE), heat shock response (HdlD, GrpE), carbon starvation response (SspA, SspB), anaerobic respiration (HybC, ErpA, GlpE), pH adaptation/ acid resistance (SpeA, SpeB, Mrp), energy metabolism: degradation of carbon compounds (GalT, BglX, EbgA, MtlD), glycolysis/ gluconeogenesis (GpmA, SucB, FdhO, FbaB, GloB, NuoC, AceF, PoxB, SdhA), amino acid metabolism (GcvT, GcvP, HslV, IlvE, GlnA, TnaA), nitrogen and glycerolipid metabolism (GlpK), DNA degradation (RecB), biosynthetic pathways: fatty acid (FabG, AccD, AccB), amino acids (DapB, ArgH, AsD, IlvA), nucleotides (PyrI, PyrC, PurH, GlmU, CmK, GuaA, GuaB, GmK,), cellulose $(\mathrm{BcsC})$, cofactors/carriers (MoaC, GshB), vitamins (RibB, PdxJ), chaperones (fimbrial usher protein,), transport (HmuV, FadL, PlaP, MacB, OppA, NikA, SecD, ManZ, PotA, YajC, EtpE), storage (BfR, FtnA), multidrug efflux systems (AcrA, MdtC), tellurite resistance (TerC), serine proteases (DegP, DegQ, EspP), outer membrane proteins/porins/channel (AsmA, LptE, Lpp, NagA, 
Table 40157 proteins up-regulated under anaerobic conditions in uRF, in Experiment II

\section{Protein/Function/Pathway; Name}

2,3-bisphosphoglycerate-dependent phosphoglycerate mutase/Glycolysis/Energy; GpmA

3-oxoacyl-[acyl-carrier-protein] reductase/Fatty acid biosynthesis; FabG

3,4-dihydroxy-2-butanone 4-phosphate synthase, Riboflavin (Vitamin B2) biosynthesis/ Cofactor Bisoynthesis; RibB 30 ribosomal protein S6/Protein Translation; RpsF

4-hydroxy-tetrahydrodipicolinate reductase, Leucine synthesis/Amino acid Biosynthesis; DapB

50 ribosomal protein L10/Protein Translation; RpIJ

50 ribosomal protein L18/Protein Translation; RpIR

Acetyl-coenzyme A carboxylase carboxyl transferase subunit beta/Fatty acid Biosynthesis; AccD

Acriflavine resistance protein A/Multidrug efflux system/Transport; AcrA

ADP-L-glycero-D-manno-heptose-6-epimerase/LPS core Biosynthesis/Heat induced; HIdD

Agmatinase/Polyamine Biosynthesis/Acid Resistance; SpeB

AidA-I adhesin-like protein/Adherence; AidA

Aminomethyltransferase/Nitrogen, Amino Acid Metabolism; GcvT

Argininosuccinate lyase, Arginine synthesis/ Amino Acid Biosynthesis; ArgH

AsmA protein/LPS Biogenesis; AsmA

Aspartate carbamoyltransferase regulatory chain/Nucleotide Biosynthesis; Pyrl

Aspartate-tRNA ligase/Aminoacyl-tRNA Biosynthesis; AspS

Aspartate-semialdehyde dehydrogenase/Amino acid Biosynthesis; AsD

ATP synthase subunit b/Energy Production; AtpF

ATP-dependent helicase/DNA Replication, Repair; HrpB

ATP-dependent protease subunit/Proteolysis; HsIV

Bacterioferritin/Iron storage and Transport; BfR

Bacteriophage replication gene A protein/Predicted Phage replication; ECH74115_3058

Beta-D-glucoside glucohydrolase, degradation of small carbon compunds/Biosyntheis of secondary metabolites; BgIX

Bifunctional N-acetylglucosamin-1-phosphate-uridyl transferase/Cell Wall Synthesis; GImU

Bifunctional purine biosynthesis protein/Purine Biosynthesis; PurH

Biofilm regulator/Biofilms, Adherence; BssR

Biosynthetic arginine decarboxylase/Polyamine Biosynthesis, Acid Resistance; SpeA

Biotin carboxyl carrier protein of acetyl-CoA carboxylase/Fatty Acid Biosynthesis; AccB

Branched-chain-amino-acid aminotransferase/Amino acid Transport and Metabolism; IlvE

Catabolite repression sensor kinase for PhoB alternative sensor for pho regulon/Global Regulaor; CreC

Catalase-peroxidase 1/Prevent Cell, DNA damage/Oxidative Stress; KatG1

Cell Division protein; ZapB

\section{Accession Number}

Molecular Weight $(\mathrm{kDa})^{1}$

GPMA_ECO57

$29 \mathrm{kDa}$

Q8X815_ECO57

$26 \mathrm{kDa}$

RIBB_ECO57

$23 \mathrm{kDa}$

RS6_ECO57

$15 \mathrm{kDa}$

DAPB_ECO57

$29 \mathrm{kDa}$

RL10_ECO57

$18 \mathrm{kDa}$

RL18_ECO57

$13 \mathrm{kDa}$

ACCD_ECO57

$33 \mathrm{kDa}$

$44 \mathrm{kDa}$

$35 \mathrm{kDa}$

HLDD ECO57

SPEB_ECO57 (+1)

$34 \mathrm{kDa}$

KOAT24_ECO1C

GCST_ECO57

$141 \mathrm{kDa}$

$40 \mathrm{kDa}$

ARLY_ECO57

$50 \mathrm{kDa}$

B5YUC4_ECO5E (+5)

$69 \mathrm{kDa}$

PYRI_ECO57

$17 \mathrm{kDa}$

SYD_ECO57 (+1)

$66 \mathrm{kDa}$

DHAS_ECO57

$40 \mathrm{kDa}$

ATPF_ECO57

$17 \mathrm{kDa}$

Q8X904_ECO57 (+1)

$91 \mathrm{kDa}$

HSLV_ECO57

$19 \mathrm{kDa}$

Q8X890_ECO57

$18 \mathrm{kDa}$

B5YUH3_ECO5E

Q8X668_ECO57

$86 \mathrm{kDa}$

$83 \mathrm{kDa}$

GLMU_ECO57 (+2)

$49 \mathrm{kDa}$

PUR9_ECO57

BSSR_ECO57

SPEA_ECO57

BCCP_ECO57 (+8)

ILVE_ECO57

Q8XB07_ECO57

KATG1_ECO57

ZAPB_ECO5E (+8)
$57 \mathrm{kDa}$

$15 \mathrm{kDa}$

$74 \mathrm{kDa}$

$17 \mathrm{kDa}$

$34 \mathrm{kDa}$

$52 \mathrm{kDa}$

$80 \mathrm{kDa}$

$9 \mathrm{kDa}$ 
Table 40157 proteins up-regulated under anaerobic conditions in uRF, in Experiment II (Continued)

Cellulose synthase subunit/Biofilms, Adherence; BcsC

Chromosome partition protein/Cell Division; MukB

Curli production assembly/transport subunit/Biofilms, Adherence; CsgG

Cyclic pyranopterin monophosphate synthase accessory protein/Cofactor Biosynthesis; MoaC

Cytidylate kinase/Nucleotide Biosynthesis; $\mathbf{C m k}$

Dihydrolipoyllysine-residue succinyltransferase component of 2-oxoglutarate dehydrogenase

Complex/Energy Metabolism; SucB

Dihydroorotase/Nucleotide Biosynthesis; PyrC

DNA helicase/DNA Replication, Transcription; RecB

DNA invertase from prophage CP-933H/DNA Replication; PinH

DNA topoisomerase IV subunit B/DNA Replication; ParE

DNA-directed RNA polymerase subunit alpha/DNA Transcription; RpoA

DNA-directed RNA polymerase subunit beta/DNA Transcription; RpoB

DNA-directed RNA polymerase subunit omega/DNA Transcription; RpoZ

Elongation factor P-like protein/Translation, Protein synthesis; YeiP

Evolved beta-D-galactosidase alpha subunit/Degradation of small carbon compounds; EbgA

Ferritin-1/Iron Uptake and Storage; FtnA

Fimbrial usher family protein/Chaperone/Transport; ECH74115_2118

Formate dehydrogenase-O major subunit/Energy Metabolism, Anaerobic Respiration; FdoH

Fructose-bisphosphate aldolase, class 1/Glycolysis, Gluconeogensis; FbaB

Galactose-1-phosphate uridylyltransferase/Galactose Metabolism; GalT

Glucans biosynthesis protein G/Osmotic Adaptation; MdoG

Glutamate-tRNA ligase/Amino acyl tRNA synthesis; GItX

Glutamine synthetase/Amino acid Biosynthesis; GInA

Glutathione synthetase/Cofactors, carriers Biosynthesis; GshB

Glycerol kinase/Glycerolipid Metabolism; GlpK

Glycine dehydrogenase [decarboxylating]/Amino acid Metabolism; GcvP

GMP synthase [glutamine-hydrolyzing]/Nucleotide Biosynthesis; GuaA

GTPase-activating protein/Transcriptional Activator; Yihl

Guanylate kinase/Nucleotide Biosynthesis; GmK

Hemin import ATP-binding protein/Transport; HmuV

Histidine-tRNA ligase/Amino acyl tRNA synthesis; HisS

HTH-type transcriptional regulator/Maltooligosaccharide Uptake and Metabolism; MalT

C8TYF1_ECO10 (+2)

$126 \mathrm{kDa}$

MUKB_ECO57 (+2)

$170 \mathrm{kDa}$

B5YVQ8_ECO5E (+1)

$31 \mathrm{kDa}$

MOAC_ECO57

$17 \mathrm{kDa}$

KCY_ECO57

$25 \mathrm{kDa}$

ODO2_ECO57

PYRC_ECO57

Q8X6M9_ECO57

$44 \mathrm{kDa}$

$39 \mathrm{kDa}$

$134 \mathrm{kDa}$

Q8X7L1_ECO57

$22 \mathrm{kDa}$

$70 \mathrm{kDa}$

Q8XBQ4_ECO57

RPOA_ECO57

RPOB_ECO57

$37 \mathrm{kDa}$

$151 \mathrm{kDa}$

RPOZ_ECO57

EFPL_ECO57

Q8XAM9_ECO57

$10 \mathrm{kDa}$

$22 \mathrm{kDa}$

$119 \mathrm{kDa}$

FTNA_ECO57

$19 \mathrm{kDa}$

B5Z1W3_ECO5E (+5)

$81 \mathrm{kDa}$

$113 \mathrm{kDa}$

Q7A9A6_ECO57 (+1)

$38 \mathrm{kDa}$

B5Y44_ECO5E $(+1)$

$40 \mathrm{kDa}$

Q8X943_ECO57

$59 \mathrm{kDa}$

$54 \mathrm{kDa}$

SYE_ECO57

GLNA_ECO57

GSHB_ECO57

GLPK_ECO57

GCSP_ECO57

GUAA_ECO57

YIHI_ECO57

KGUA_ECO57 (+2)

HMUV_ECO57

SYH_ECO57 
Table 40157 proteins up-regulated under anaerobic conditions in uRF, in Experiment II (Continued)

Hydrogenase-2 large chain/Energy Metabolism/Anaerobic Respiration; HybC

Hydroxyacylglutathione hydrolase/Pyruvate Metabolism; GloB

Inosine-5'-monophosphate dehydrogenase/Nucleotide Biosynthesis; GuaB

Iron-sulfur cluster insertion protein/Growth using alternate electron acceptors; ErpA

Long-chain fatty acid transport protein/Transport; FadL

Low-affinity putrescine importer/Transport; PlaP

LPS-assembly lipoprotein/LPS Biogenesis; LptE

Macrolide export ATP-binding/permease protein/Transport; MacB

Major outer membrane lipoprotein/Membrane Integrity; Lpp

Mannitol-1-phosphate 5-dehydrogenase/Fructose, Mannose Metabolism; MtID

Membrane, TerC family/CBS/transporter associated protein/Transport/Tellurium Resistance; TerC Methyl-accepting chemotaxis protein III, ribose and galactose sensor receptor/Chemotaxis; Trg

Minor curlin protein/Biofilms, Adherence; CsgB

Multiple Resistance and pH adaptation protein, antiporter/Transport; Mrp

Multidrug resistance efflux protein/Transport; $\mathbf{M d t C}$

Multiphosphoryl transfer protein/Fructose, Mannose Metabolism; FruB

$\mathrm{N}$-acetylglucosamine-6-phosphate deacetylase/LPS Biosynthesis; NagA

$\mathrm{NADH}$-quinone oxidoreductase subunit C/D/Electron transfer/Energy Metabolism; NuoC

NifU-like protein/Energy Production, Conversion; NifU

Non-LEE-encoded type III secreted effector; EspX7

Oligopeptide ABC transporter, periplasmic oligopeptide-binding protein/Transport; OppA

Osmotically-inducible lipoprotein E/Global Regulator; OsmE

Outer membrane lipoprotein/Cell Envelope Biogenesis; SlyB

Outer membrane protein, porin, receptor, integrity/Membrane Stability; OmpA

Outer membrane protein assembly factor/Membrane Assembly, Antibiotic Resistance; BamA/YaeT

Outer membrane protein assembly factor/Membrane Assembly, Antibiotic Resistance; BamD/YfiO

Outer membrane protein, efflux protein/Transport; TolC

Outer membrane protein W/Outer Membrane Biogenesis; OmpW/YciD

Oxidoreductase subunit/Oxidative Stress; DmsA_YnfF

Penicillin-binding protein activator/Lipid binding/Putative Adhesin; LpoB/YcfM

Peptidase B/Protein Metabolism; PepB

Peptide chain release factor 1/Protein Translation; PrfA

Peptidyl-prolyl cis-trans isomerase A/Post-translational Modification; PpiA

MBHM_ECO57

GLO2_ECO57

$\begin{array}{ll}\text { B5ZOX7_ECO5E } & 54 \mathrm{kDa} \\ \text { ERPA_ECO57 } & 12 \mathrm{kDa}\end{array}$

FADL_ECO57 $49 \mathrm{kDa}$

PLAP_ECO57 $50 \mathrm{kDa}$

LPTE_ECO57 $21 \mathrm{kDa}$

MACB_ECO57 $71 \mathrm{kDa}$

LPP_ECO57 $8 \mathrm{kDa}$

MTLD_ECO57 $41 \mathrm{kDa}$

B5YUC1_ECO5E (+6) $59 \mathrm{kDa}$

C8U899_ECO10 $59 \mathrm{kDa}$

B5YVR3_ECO5E (+1) $17 \mathrm{kDa}$

B5Y63_ECO5E $(+1) \quad 40 \mathrm{kDa}$

C8TU07_ECO26 (+2) $111 \mathrm{kDa}$

PTFAH_ECO57 $40 \mathrm{kDa}$

NAGA_ECO57 $41 \mathrm{kDa}$

NUOCD_ECO57 (+2) $\quad 69 \mathrm{kDa}$

NIFU_ECO57 $14 \mathrm{kDa}$

C6URC5_ECO5T (+2) $73 \mathrm{kDa}$

B5YYE8_ECO5E $63 \mathrm{kDa}$

OSME_ECO57 $12 \mathrm{kDa}$

SLYB_ECO57 $16 \mathrm{kDa}$

B5YT87_ECO5E $38 \mathrm{kDa}$

BAMA_ECO57 $91 \mathrm{kDa}$

BAMD_ECO57 $28 \mathrm{kDa}$

B5YR81_ECO5E (+2) $54 \mathrm{kDa}$

Q8XCB6_ECO57 $23 \mathrm{kDa}$

C6UV29_ECO5T (+6) $\quad 90 \mathrm{kDa}$

LPOB_ECO57 $23 \mathrm{kDa}$

PEPB_ECO57 $46 \mathrm{kDa}$

RF1_ECO57 $41 \mathrm{kDa}$

PPIA_ECO57 $20 \mathrm{kDa}$ 
Table 40157 proteins up-regulated under anaerobic conditions in uRF, in Experiment II (Continued)

\section{Peptidyl-prolyl cis-trans isomerase/Post-translational Modification; FkIB}

Periplasmic binding protein for nickel/Amino acid Transport and Metabolism; NikA

Phenylalanine-tRNA ligase alpha subunit/Amino acyl tRNA synthesis; PheS

Phenylalanine-tRNA ligase beta subunit/Amino acyl tRNA synthesis; PheT

Poly (A) polymerase I/DNA Transcription; PcnB

Proline-tRNA ligase/Amino acyl tRNA synthesis; ProS

Protease IgA1, Serine protease/Protection; EspP

Protein elaB/Uncharacterized; ElaB

Protein grpE, prevents aggregation of denatured proteins/ Heat and Hyperosmotic Shock-Related; GrpE

Protein translocase subunit//ransport; SecD

PTS system, mannose-specific transporter subunit IID/Transport; ManZ

Putative anaerobic dimethyl sulfoxide reductase chain A; DmsA_YnfE

Putative DNA replication factor encoded within cryptic prophage CP-933P/Hypothetical; Z6069

Putative endopeptidase of prophage CP-933X/Hypothetical; Z1877

Putative carboxypeptidase/Hypothetical; YagX

Putative lipoprotein induced during stationary phase/Stress Response; YbjP

Putative homeobox protein/Regulator; Ybgs

Putative lipoprotein/Membrane protein; LppC

Putative membrane protein, peptidase/Uncharacterized; YibP

Putative multimodular enzyme/Energy Metabolism; Z3719

Putative pectinesterase, localizes to cellular poles/Membrane protein; YbhC

Putative replicase/DNA Replication; $\mathbf{Z 5 1 8 7}$

Pyridoxine 5'-phosphate synthase/Vitamin B6 (Pyridoxine) synthesis; PdxJ

Pyruvate dehydrogenase (Dihydrolipoyltransacetylase component)/Energy Metabolism; AceF

Pyruvate oxidase/Degradation of small carbon compunds; PoxB

RNase E/RNA Degradation; RnE

Serine protease/Protection; DegP

Serine endoprotease/Protection; DegQ

Single-stranded DNA-binding protein/DNA Replication; SsB

Soluble cytochrome, electron transport/Energy Metabolism; CybC

Spermidine/putrescine import ATP-binding protein/Transport; PotA

Stringent starvation protein A, stationary phase induced acid tolerance/Global Regulator; SspA

Stringent starvation protein B, ClpXP protease specificity enhancer/Global Regulator; SspB

B5Z2L4_ECO5E (+2)

Q8X5U3_ECO57 (+1)

$22 \mathrm{kDa}$

$59 \mathrm{kDa}$

SYFA_ECO57 (+2)

$37 \mathrm{kDa}$

SYFB_ECO57

$87 \mathrm{kDa}$

PCNB_ECO57 (+3)

$54 \mathrm{kDa}$

SYP_ECO57

$64 \mathrm{kDa}$

KOAWD8_ECO1C

$146 \mathrm{kDa}$

ELAB_ECO57

$11 \mathrm{kDa}$

C8U980_ECO10 (+2) $22 \mathrm{kDa}$

SECD_ECO57

$67 \mathrm{kDa}$

B5YQW0_ECO5E $(+1)$

$31 \mathrm{kDa}$

Q7ABM3_ECO57 (+1)

$88 \mathrm{kDa}$

Q8XAD9_ECO57

$28 \mathrm{kDa}$

Q8X704_ECO57

$12 \mathrm{kDa}$

Q8X614_ECO57 (+1)

$91 \mathrm{kDa}$

Q8X6N7_ECO57 (+1)

$19 \mathrm{kDa}$

Q8X948_ECO57

$13 \mathrm{kDa}$

B5YUN1_ECO5E

Q8XDE2_ECO57

Q8XBF4_ECO57

$20 \mathrm{kDa}$

$47 \mathrm{kDa}$

$82 \mathrm{kDa}$

Q8X891_ECO57

$46 \mathrm{kDa}$

Q8XBZ7_ECO57

PDXJ_ECO57

$37 \mathrm{kDa}$

$26 \mathrm{kDa}$

Q8X966_ECO57

$66 \mathrm{kDa}$

Q8X6L4_ECO57

$62 \mathrm{kDa}$

Q8X8J5_ECO57

$118 \mathrm{kDa}$

B5Z0E1_ECO5E (+1)

$49 \mathrm{kDa}$

Q8X9F1_ECO57

$47 \mathrm{kDa}$

SSB_ECO57

$19 \mathrm{kDa}$

C562_ECO57 (+4)

POTA_ECO57

$14 \mathrm{kDa}$

SSPA_ECO57

$43 \mathrm{kDa}$

SSPB_ECO57 
Table 40157 proteins up-regulated under anaerobic conditions in uRF, in Experiment II (Continued)

Succinate dehydrogenase flavoprotein subunit/Energy Metabolism; SdhA

DHSA_ECO57

$64 \mathrm{kDa}$

Tat-linked quality control protein/DNAse activity; TatD

Thiosulfate sulfurtransferase/Anaerobic Respiration, Energy Metabolism; GlpE

Threonine deaminase (Dehydratase)/Amino acid Biosynthesis; IlvA

Transcription termination/antitermination protein/Modulates DNA Transcription; NusG

Transcriptional regulatory protein/Envelope Stress Response Protein/Downregulates LEE; CpxR

Transketolase 1, thiamin-binding/Non-oxidative Metabloism; TktA

Transketolase 2 isozyme, stationary phase induced/Non-oxidative Metabolism; TktB

Translation initiation factor IF-2/Protein Translation; InfB

Trigger factor/Cell division; TiG

Tryptophanase/Tryptophan Metabolism, Indole Production; TnaA

Type II secretion pathway related protein/Transport; EtpE

Tyrosine-protein kinase/Downregulates colanic acid production; WzC

Uncharacterized protein/Hypothetical; ECs1547

Uncharacterized protein/Hypothetical; ECs2891

Uncharacterized protein/Hypothetical; ECs2991

Putative oxidative stress defense protein/ Oxidative Stress; YggE

Uncharacterized protein/Membrane Protein; YqjD

UPF0042 nucleotide-binding protein/putative ATPase; YhbJ

UPF0092 membrane protein, translocase/Transport; YajC

UPF0337 protein, putative stress response protein/Osmotic Shock; YjbJ

Q8X8J6_ECO57

$30 \mathrm{kDa}$

C8TJL4_ECO26 (+2)

$12 \mathrm{kDa}$

Q8X467_ECO57

$56 \mathrm{kDa}$

NUSG_ECO57

$21 \mathrm{kDa}$

CPXR_ECO57

$26 \mathrm{kDa}$

C8TGU9_ECO26

$72 \mathrm{kDa}$

Q8XBF1_ECO57 (+6)

$73 \mathrm{kDa}$

IF2_ECO57

$97 \mathrm{kDa}$

TIG_ECO57 (+1)

$48 \mathrm{kDa}$

TNAA_ECO57

O82884_ECO57

$53 \mathrm{kDa}$

$56 \mathrm{kDa}$

WZC_ECO57

$79 \mathrm{kDa}$

Q8X3G9_ECO57 (+1) $17 \mathrm{kDa}$

Q8X7H8_ECO57 $14 \mathrm{kDa}$

Q8X2Z1_ECO57 $10 \mathrm{kDa}$

YGGE_ECO57 $27 \mathrm{kDa}$

YQJD_ECO57 $11 \mathrm{kDa}$

YHBJ_ECO57 $32 \mathrm{kDa}$

YAJC_ECO57 $12 \mathrm{kDa}$

YJBJ_ECO57 $8 \mathrm{kDa}$

UPF0352 protein/Uncharacterized; YejL

Uridylate kinase/Nucleotide Interconversion; PyrH

Valine-tRNA ligase/Amino acyl tRNA Biosynthesis; Vals

YEJL_ECO57

$8 \mathrm{kDa}$

PYRH_ECO57

$26 \mathrm{kDa}$

${ }^{1} \mathrm{kDa}$, Kilodalton.

SY_ECO57

$108 \mathrm{kDa}$ 
SlyB, OmpA, BamA, BamD, TolC, OmpW, ElaB, YbjP, LppC, YqjD), chemotaxis (Trg), adherence (AidA-like, BssR, CsgG, CsgB, LpoB/YcfM, EspP), and cell division/ DNA replication (HrpB, ZapB, MukB, ParE, Ssb, Tig) (Table 4; Additional file 2: Table S2).

\section{Discussion}

This study provides a snapshot of various proteins expressed by $\mathrm{O} 157$ in unfiltered, rumen fluid through a comparative analysis of the $\mathrm{O} 157$ proteomic-profile in different media, growth conditions and incubation times. Interestingly, none of the reported (LEE, Shiga toxins) O157 virulence proteins were detected, under all conditions, in any media tested. Overall, fewer O157 proteins were detected in more nutritionally complex RF-preparations versus LB and among these, differences were observed based on availability of oxygen, nutrients and incubation time. Also, the O157-proteome in the RF-preparations included more proteins with diverse functions at $48 \mathrm{~h}$ than after 14 days of incubation. In fact, proteins associated with adherence, cell division and growth were identified only at $48 \mathrm{~h}$. However, under all conditions, a selective expression of proteins with a role in cell structure, transport, metabolism, chemotaxis, motility, resistance, stress and regulation was observed in RF-preparations, many of which were up-regulated in the unfiltered rumen fluid. The $\mathrm{O} 157$ growth patterns and proteome expressed in the rumen fluid is suggestive of an adapting O157, expending minimal energy, preparing for survival and downstream intestinal colonization.

Since adult cattle are often fed a maintenance diet with less protein until ready for feedlots, we decided to analyze O157 growth dynamics in rumen fluid derived from animals on this diet. Rumen fluid from cattle fed a diet low in protein usually has a $\mathrm{pH}$ ranging from 6.2-6.8, and VFA concentrations at, $60-70 \%$ acetic acid, $15-20 \%$ propionic acid, 5-15\% butyric acid [28-31]. The rumen fluid VFA and $\mathrm{pH}$ values were within the limits described for this diet for both animals used in this study (Tables 1 and 2; 26-29). Irrespective of incubation times (14 days versus $48 \mathrm{~h}$ ), O157 exhibited very distinctive growth patterns in RF-preparations compared to LB. O157 cultures in $\mathrm{dRF}$, fRF and uRF were consistently at lower optical densities than LB, under both aerobic and anaerobic conditions. The anaerobic RF-preparation cultures never reached an $\mathrm{OD}_{600} \cong 1.0$ and the viable $\mathrm{O} 157$ recovered were at substantially lower counts when compared to LB. The low OD readings and viable counts recovered from RF-preparation grown cultures may have been due to inhibitory factors and /or limited nutrients in dRF, fRF, uRF, not seen in LB, having a bacteriostatic (aerobic) or bactericidal (anaerobic) effect on O157 and reflective of O157 growth in a stressful environment [11,32-36]. Using LB media for estimating viable counts may have helped recover the stressed bacteria [35]. Similar recovery of viable bacteria despite low OD reading has been reported among bacteria exposed to antimicrobial stress [36], and limited growth has been associated with bacteria entering into a stressed/ starved state or stationary phase [35-37].

Overall, fewer O157 proteins were detected in RFpreparation cultures compared to LB, especially under anaerobic conditions. Irrespective of the media used to culture O157, its anaerobic proteome was functionally associated only with cell structure, transport, metabolism, chemotaxis, motility, resistance, stress-related and regulation, and not O157 virulence. Previous reports have demonstrated that $\mathrm{O} 157$ virulence genes, especially the Shiga toxin and LEE-encoded genes, are downregulated in LB compared to minimal media [38-40]. In addition, presence of trace amounts of glucose has also been shown to down-regulate LEE expression due to catabolite repression and/or acidic $\mathrm{pH}$ [38-40]. Hence, the lack of virulence gene expression in LB in this study conforms to those findings. Experiments with acidstressed, starved bacteria have shown that these are likely to be more virulent only on recovery, and over time [35]. Even in minimal media that usually supports O157 virulence gene expression, several of these are suppressed as cultures reach the stationary phase [41]. Butyrate, a key environmental cue in LEE gene expression was limited in the RF used in this study, which may have also caused the LEE suppression [9]. Conditioned media from unrelated cultures have been shown to suppress Shiga toxin gene expression while maintaining O157 growth or suppressing growth itself [33,35,42]. In fact, experimental studies have shown that it is easier to displace $\mathrm{O} 157$ in unfiltered rumen fluid versus autoclaved rumen fluid, by addition of "nonfermentable" sugars in the presence of the ruminal microflora [11]. Thus, the absence of $\mathrm{O} 157$ virulence gene expression in RF-preparations may be reflective of the stressful growth environment, suppression due to nutrient limitations, lack of inducers, oxygen deprivation, $\mathrm{pH}$ fluctuations and inhibitory metabolites released by resident microbiota.

Previous studies have suggested development of acid resistance by Shiga-toxin producing E. coli (STEC) in the rumen as a means for better STEC survival through the 'stomach-like' acidic bovine abomasum [43,44] and have prescribed a role for glutamate-dependent acid resistance system (Gad system) and the tryptophanase ( $\operatorname{tnaA})$ enzyme toward this end [45]. Hughes et al., recently demonstrated that O157 LEE expression is downregulated while the Gad system is up-regulated in the rumen of cattle [46]. This observation made in animals being fed a grain diet, having a ruminal $\mathrm{pH}$ of 5.93, derived a role for the SdiA gene in sensing the acylhomoserine lactone (AHL) signals in the rumen fluid and affecting differential expression of these genes. AHLs 
formed by ruminal resident flora, are effective only under highly acidic $\mathrm{pH}$ and hydrolyze at neutral-alkaline $\mathrm{pH}[46,47]$. Similarly, the Gad system that relies on the decarboxylation $(\operatorname{gad} A / B)$ of glutamate via proton consumption to increase cytoplasmic alkalinity is active at pH 4-4.6 [48]. However, other degradative amino acid decarboxylase and acid-resistance systems are activated in response to low $\mathrm{pH}$ (5.2 to 6.9), fermentativeanaerobic growth and stationary phase growth $[48,49]$ and used more often than the Gad system to counter the deleterious effects of protons. We observed one such system, the arginine-dependent acid resistance system (Arg system) to be up-regulated in the RF-preparations after $48 \mathrm{~h}$ of anaerobic growth. Since the pH of the RFpreparations used in this study did not reach extreme acidic levels, the Gad system may not have been induced. In the Arg system, decarboxylation (speA) of arginine via proton consumption resulting in the formation of agmatine stabilizes the cytoplasmic $\mathrm{pH}$. Agmatine is either exported via the arginine-agmatine antiporter (aidC) or converted (speB) to putresceine as part of the polyamine biosynthetic pathway.

Considering that $\mathrm{O} 157$ is exposed to heat-shock, starvation and stationary-phase-like growth in the rumen, it is possible that these factors enhance acid-tolerance in the bacteria through other mechanisms such as outer membrane changes and synthesis of proton transportrelated protective proteins, as well $[49,50]$. Several stress (acid, low oxygen, osmolites, stationary phase)-responsive genes were expressed by $\mathrm{O} 157$ in this study, and included genes associated with the metabolism of arginine (speA, speB), lysine $($ lys $U)$, formate $(h y C)$, tryptophan $(\operatorname{tna} A)$ and maltoporin $(\operatorname{lamB})$, catalase $(k a t G)$, DNA polymerase-1 (polA) and AidA-1 adhesin-like protein (aidA) [49-51]. Flagellar genes are differentially expressed under varying acid-stress conditions [51-53], and in our study, these genes were up-regulated in dRF and fRF but not uRF, suggesting less $\mathrm{pH}$ variation in the course of growth in $\mathrm{uRF}$ and limiting the role of flagella to motility alone. Stressed bacteria have been shown to be more adherent $[35,40,53]$; proteins associated with adherence (AidA-1 adhesin-like) and biofilm formation (BssR, CsgG, CsgB) were identified after $48 \mathrm{~h}$ incubation and not after longer incubation periods. Interestingly, several 'resistance' related proteins were up-regulated in RF-preparations, a subset of which (tellurite resistance, serine protease) have also been shown to contribute towards O157 adherence $[54,55]$. This suggests that adherence may be critical during the initial phase of O157 colonization and although LEE is suppressed, the bacteria rely on other mechanisms to adhere or form biofilms in the rumen. It has been observed that bacteria and protozoa in the rumen tend to adhere to the fibrous mat layers comprising of plant material to remain in the rumen and assist in the digestion of insoluble feed materials [56]. While this may not be in the case of O157, initial adherence to or biofilm formation on available surfaces may give the bacteria time to adapt and survive the rumen environment [34]. It appears that much of the adaptive changes are initiated early in colonization as reflected in more stress-induced, structural integrityrelated outer membrane proteins (AsmA, LptE, Lpp, NagA, SlyB, OmpA, BamA, BamD, TolC, OmpW, ElaB, YbjP, LppC, YqjD), and cell division and growth proteins, being expressed at $48 \mathrm{~h}$. This supports the observation that $\mathrm{O} 157$ is maintaining slow growth in the RF-preparations as well.

\section{Conclusion}

Bottom-up proteomics provided a broad picture of differences in O157 protein expression after extended incubation in various media tested. Quantitative proteomics (iTRAQ)-based analysis of the O157 anaerobic proteome expressed in URF with all normal rumen flora was performed to more closely determine $\mathrm{O} 157$ protein expression in the bovine rumen. The cumulative results of all RF-preparation analysis suggested that rumen specific protein expression enables O157 to adapt to this hostile environment and successfully transit to its colonization sites in the bovine GIT. To further verify our conclusions, we are evaluating the $\mathrm{O} 157$ proteomic-profile as expressed in vivo in a rumen-fistulated cow, and confirming the role of a subset of these 'adaptive' proteins in O157 survival.

\section{Additional files}

Additional file 1: Table S1. Bottom-up Proteomics Dataset.

Additional file 2: Table S2. ITRAQ Proteomics Dataset.

Competing interests

The authors declare no competing financial interests.

\section{Authors' contributions}

ITK was the project leader and designed, coordinated, conducted experiments, analyzed results, interpreted data and drafted the manuscript. TBS assisted in design of experiments, VFA analysis, interpreted results and contributed to the final draft of the manuscript. JDL conducted iTRAQ proteomics, verified data generated and contributed to the final draft of the manuscript. All authors read and approved the final manuscript.

\section{Acknowledgements}

Technical support provided by Bryan Wheeler, Deb Hinrichsen (NVSL) and Laurie Evans (NVSL) in collection \& filtration of rumen fluid; Deb Lebo and Sam Humphrey in analyzing VFAs; Duane Zimmerman for assisting with iTRAQ labeling and Paul Amundson's group of animal caretakers for assisting in rumen fluid collection is acknowledged with appreciation. Bottom-up proteomics was done at the Proteomics Division, ICBR, University of Florida, Gainesville, FL. We thank Dr. Manohar John, Dr. Thomas Casey and Dr. John Bannantine for their insightful review of this manuscript.

\section{Disclaimer}

Mention of trade names or commercial products in this article is solely for the purpose of providing specific information and does not imply recommendation 
or endorsement by the U.S. Department of Agriculture. USDA is an equal opportunity provider and employer.

\section{Author details}

${ }^{1}$ Food Safety and Enteric Pathogens Research Unit, National Animal Disease Center, Agricultural Research Service, U.S. Department of Agriculture, Ames, lowa 50010, USA. ${ }^{2}$ Ruminant Diseases and Immunology Research Unit, National Animal Disease Center, Agricultural Research Service, U.S. Department of Agriculture, Ames, lowa 50010, USA.

Received: 6 November 2013 Accepted: 10 February 2014 Published: 21 February 2014

\section{References}

1. Scallan E, Hoekstra RM, Angulo FJ, Tauxe RV, Widdowson M, Roy SL, Jones JL, Griffin PM: Foodborne illness acquired in the United States - Major pathogens. J Animal Sci 2011, 17:7-15.

2. Vital signs: Incidence and trends of infection with pathogens transmitted commonly through food -- Foodborne diseases active surveillance network, 10 U.S. Sites, 1996-2010. MMWR 2011, 60:749-755.

3. CDC: Preliminary FoodNet data on the incidence of infection with pathogens transmitted commonly through food-10 sites, United States, 2004. MMWR 2005, 54:352-356.

4. Griffin PM, Ostroff SM, Tauxe RV, Greene KD, Wells JG, Lewis JH, Blake PA: Illnesses associated with Escherichia coli 0157:H7 infections A broad clinical spectrum. Ann Intern Med 1998, 109:705-712.

5. Kaper JB, O'Brien AD: Escherichia coli O157:H7 and other Shiga Toxin-Producing E. coli Strains. Washington, D.C: ASM Press; 1998.

6. Wolin MJ: Volatile fatty acids and the inhibition of Escherichia coli growth by rumen fluid. Appl Microbiol 1969, 17:83-87.

7. Schneider IC, Ames ML, Rasmussen MA, Reilly PJ: Fermentation of cottonseed and other feedstuffs in cattle rumen fluid. J Agric Food Chem 2002, 50:2267-2273.

8. Rasmussen MA, Cray WC Jr, Casey TA, Whipp SC: Rumen contents as a reservoir of enterohemorrhagic Escherichia coli. FEMS Microbiol Lett 1993, 114:79-84.

9. Nakanishi N, Tashiro K, Kuhara S, Hayashi T, Sugimoto N, Tobe T: Regulation of virulence by butyrate sensing in enterohaemorrhagic Escherichia coli. Microbiol 2009, 155:521-530.

10. Gylswyk NO, Wejdemar K, Kulander K: Comparative growth rates of various rumen bacteria in clarified rumen fluid from cows and sheep fed different diets. Appl Enivron Microbiol 1992, 58:99-105.

11. De Vaux A, Morrison M, Hutkins RW: Displacement of Escherichia coli 0157:H7 from rumen medium containing prebiotic sugars. Appl Environ Microbiol 2002, 68:519-524.

12. Kudva IT, Dean-Nystrom E: Bovine recto-anal junction squamous epithelial (RSE) cell adhesion assay for studying Escherichia coli 0157 adherence. J App Microbiol 2011, 111:1283-1294.

13. Nikkhah $A$ : Bioscience of ruminant intake evolution: Feeding time models. Adv Biosci Biotech 2011, 2:271-274.

14. Allison MJ, Robinson IM, Bucklin JA, Booth GD: Comparison of bacterial populations of the pig cecum and colon based upon enumeration with specific energy sources. Appl Environ Microbiol 1979, 37:1142-1151.

15. Lambert MA, Moss CW: Preparation and analysis of the butyl esters of short-chain volatile and non-volatile fatty acids. Adv Chromatogr 1972, 74:335-338.

16. Salanitro JP, Muirhead PA: Quantitative method for the gas chromatographic analysis of short-chain monocarboxylic and dicarboxylic acids in feremetnation media. Appl Environ Microbiol 1975, 29:374-381.

17. Kudva IT, Krastins B, Sheng H, Griffin RW, Sarracino DA, Tarr PI, Hovde CJ, Calderwood SB, John M: Proteomics-based expression library screening (PELS): a novel method for rapidly defining microbial immunoproteomes. Mol Cell Proteomics 2006, 5:514-519.

18. Anderson $\mathrm{KL}$, Whitlock JE, Harwood VJ: Persistence and differential survival of fecal indicator bacteria in subtropical waters and sediments. Appl Environ Microbiol 2005, 71:3041-3048.

19. Gray FV, Pilgrim AF: Fermentation in the rumen of the sheep. J Exp Biol 1951, 28:74-82.

20. Owens FN, Kazemi M, Galyean ML, Mizwicki KL, Solaiman SG: Ruminal turnover rate - Influence of feed additives, feed intake and roughage level.
Oklahoma: Animal Science Research Report of the Oklahoma Agricultural Research Station; 1979.

21. Welch JG: Rumination, particle size and passage from the rumen. (1982) Rumination, particle size, and passage from the rumen. 1982, 54:885-894.

22. Keller A, Nesvizhskii Al, Kolker E, Aebersold R: Empirical statistical model to estimate the accuracy of peptide identifications made by MS/MS and database search. Anal Chem 2002, 74:5383-5392.

23. Li YF, Radivojac P: Computational approaches to protein inference in shotgun proteomics. BMC Bioinformatics 2012, 13(Suppl 16):S4. doi:10.1186/1471-2105-13-S16-S4

24. Mciiwain S, Mathews M, Bereman MS, Rubel EW, MacCoss MJ, Noble WS: Estimating relative abundances of proteins from shotgun proteomics data. BMC Bioinformatics 2012, 13:308. doi:10.1186/1471-2105-13-308.

25. Nesvizhskii Al, Keller A, Kolker E, Aebersold R: A statistical model for identifying proteins by tandem mass spectrometry. Anal Chem 2003, 75:4646-4658.

26. Lippolis JD, Bayles DO, Reinhardt TA: Proteomic changes in Escherichia coli when grown in fresh milk versus laboratory media. J Prot Res 2009, 8:149-158.

27. Delmotte N, Lasaosa M, Tholey A, Heinzle E, Huber CG: Two-dimensional reversed-phase $\times$ lon-pair reversed-phase HPLC: An alternative approach to high -resolution peptide separation for shotgun proteome analysis. J Prot Res 2007, 6:4363-4373.

28. Leng RA: Application of biotechnology to nutrition in animals in developing countries. Rome, Italy: Food and Agriculture Organization Animal Production and Health Paper, FAO/United Nations; 1991. http://www.fao.org/DOCREP/ 004/T0423E/T0423E00.HTM

29. Van Saun RJ: The discriminating rumen: Not just a food vat. College Park, PA: Pennsylvania State University Extension. http://vbs.psu.edu/extension/ resources/pdf/dairy-cow-nutrition/Ruminant\%20Nutrition-VanSaun-NAVC07. pdf/at_download/file.

30. Ruminant anatomy and physiology. St. Paul, MN: University of Minnesota Extension. http://www1.extension.umn.edu/agriculture/dairy/feed-andnutrition/feeding-the-dairy-herd/ruminant-anatomy-and-physiology.html.

31. Fluharty FL: Interactions of management and diet on final meat characteristics of beef animals. Wooster, $\mathrm{OH}$ : Ohio State University Extension. http://beef. osu.edu/library/mgtdiet.html.

32. Chaucheyras-Durand F, Madic J, Doudin F, Martin C: Biotic and abiotic factors influencing in vitro growth of Escherichia coli 0157:H7 in ruminant digestive contents. App/ Environ Microbiol 2006, 72:4136-4142.

33. Fukuda S, Toh H, Hase K, Oshima K, Nakanishi Y, Yoshimura K, Tobe T, Clarke JM, Topping DL, Suzuki T, Taylor TD, Itoh K, Kikuchi J, Morita H, Hattori M, Ohno H: Bifidobacteria can protect from enteropathogenic infection through production of acetate. Nature 2011, 469:543-549.

34. Bolton DJ, Kelly S, Lenahan M, Fanning S: In vitro studies on the effect of $\mathrm{pH}$ and volatile fatty acid concentration, as influenced by diet, on the survival of inoculated nonacid- and acid- adapted Salmonella in bovine rumen fluid and feces. Food Path Dis 2011, 8:609-614.

35. Kolling GL, Mathews KR: Influence of enteric bacteria conditioned media on recovery of Escherichia coli 0157:H7 exposed to starvation and sodium hypochlorite. J Appl Microbiol 2007, 103:1435-1441.

36. Molina-Quiroz RC, Munoz-Villagaran CM, de la Torre E, Tantalean JC, Vasquez CC, Perez-Donoso JM: Enhancing the antibiotic antibacterial effect by sub lethal tellurite concentrations: tellurite and cefotaxime act synergistically in Escherichia coli. PLoS One 2012, 7:e35452. doi:10.1371/journal.pone.0035452.

37. Sezonov G, Joseleau-Petit D, D'ari R: Escherichia coli physiology in Luria-Bertani broth. J Bacteriol 2007, 189:8746-8749.

38. Ebel F, Deibel C, Kresse AU, Guzman CA, Chakrabory T: Temperature- and medium-dependent secretion of proteins by Shiga-toxin-producing Escherichia coli. Infect Immun 1996, 64:4472-4479.

39. Medina MB, Uknalis J, Tu S: Effects of sugar addition in Luria Bertani (LB) media on Escherichia coli 0157:H7. J Food Saf 2011, 31:386-394.

40. Delcenserie V, LaPointe G, Charaslertrangsi T, Rabalski A, Griffiths MW: Glucose decreases virulence gene expression of Escherichia coli O157:H7. J Food Saf 2012, 75:748-752.

41. Bergholz TM, Wick LM, Qi W, Riordan JT, Ouellette LM, Whittam TS: Global transcriptional response of Escherichia coli O157:H7 to growth transitions in glucose minimal medium. BMC Microbiol 2007, 7:97. doi:10.1186/1471-2180-7-97.

42. Yang L, Portugal F, Bentley WE: Conditioned medium from Listeria innocua stimulates emergence from a resting state: Not a response to E. coli quorum sensing autoinducer Al-2. Biotechnol Prog 2006, 22:387-393. 
43. Tkalcic S, Brown CA, Harmon BG, Jain AV, Mueller EP, Parks A, Jacobsen KL, Martin SA, Zhao T, Doyle MP: Effects of diet on rumen proliferation and fecal shedding of Escherichia coli 0157:H7 in calves. J Food Prot 2000, 63:1630-1636.

44. Boukhors K, Pradel N, Girardeau JP, Livrelli V, Said AMO, Contrepois M, Martin C: Effect of diet on Shiga toxin-producing Escherichia coli (STEC) growth and survival in rumen and abomasum fluids. Vet Res 2002, 33:405-412.

45. Lim JY, Sheng H, Seo KS, Park YH, Hovde CJ: Characterization of an Escherichia coli 0157:H7 plasmid 0157 deletion mutant and its survival and persistence in cattle. Appl Environ Microbiol 2007, 73:2037-2047.

46. Hughes DT, Terekhova DA, Liou L, Hovde CJ, Sahl JW, Patankar AV, Gonzalez JE, Edrington TS, Rasko DA, Sperandio V: Chemical sensing in mammalian host-bacterial commensal associations. PNAS 2010, 107:9831-9836.

47. Swearingen MC, Sabag-Daigle A, Ahmer BMM: Are there acyl-homoserine lactones within mammalian intestines? J Bacteriol 2013, 195:173-179.

48. Small PLC, Waterman S: Acid stress, anaerobiosis and gadCB: lessons from Lactococcus lactis and Escherichia coli. Trends Microbiol 1998, 6:214-216.

49. Arnold KW, Kaspar CW: Starvation- and stationary-phase-induced acid tolerance in Escherichia coli 0157:H7. Appl Environ Microbiol 1995, 61:2037-2039.

50. Wang G, Doyle MP: Heat shock response enhances acid tolerance of Escherichia coli 0157:H7. Lett Appl Microbiol 1998, 26:31-34.

51. Olson ER: Influence of $\mathrm{pH}$ on bacterial gene expression. Mol Microbiol 1993, 8:5-14.

52. Maurer LM, Yohannes E, Bondurant SS, Radmacher M, Slonczewski: pH regulates genes for flagellar motility, catabolism, and oxidative stress in Escherichia coli K-12. J Bacteriol 2005, 187:304-319.

53. House B, Kus JV, Prayitno N, Mair R, Que L, Chingcuanco F, Gannon V, Cvitkovitch DG, Barnett Foster D: Acid-stress-induced changes in enterohemorrhagic Escherichia coli O157:H7 virulence. Microbiol 2009, 155:2907-2918.

54. Yin X, Wheatcroft R, Chambers JR, Liu B, Zhu J, Gyles CL: Contributions of $\mathrm{O}$-island 48 to adherence of Enterohemmorrhagic Escherichia coli 0157: $\mathrm{H} 7$ to epithelial cells in vitro and in ligated pig ileal loops. Appl Environ Microbiol 2009, 75:5779-5786

55. Dziva F, Mahajan A, Cameron R, Currie C, McKendrick, Wallis TS, Smith DGE, Stevens MP: EspP, a TypeV-secreted serine protease of enterohaemorrhagic Escherichia coli $0157: \mathrm{H} 7$, influences intestinal colonization of calves and adherence to bovine primary intestinal epithelial cells. FEMS Microbiol Lett 2007, 271:258-264.

56. McAllister TA, Bae HD, Jones GA, Cheng KJ: Microbial attachment and feed digestion in the rumen. J Anim Sci 1994, 72:3004-3018.

\section{Submit your next manuscript to BioMed Central and take full advantage of:}

- Convenient online submission

- Thorough peer review

- No space constraints or color figure charges

- Immediate publication on acceptance

- Inclusion in PubMed, CAS, Scopus and Google Scholar

- Research which is freely available for redistribution

Submit your manuscript at www.biomedcentral.com/submit
Ciomed Central 